\title{
Cyclic sedimentation pattern in Lake Veetka, southeast Estonia: a case study
}

\author{
Leili Saarse \\ Institute of Geology at Tallinn University of Technology, Ehitajate tee 5, 19086 Tallinn, Estonia; \\ e-mail: leili.saarse@ttu.ee
}

\begin{abstract}
A sediment core from Lake Veetka, southeast Estonia, $1077 \mathrm{~cm}$ in length and covering 10,500 calibrated years, was examined using loss-on-ignition, grain-size distribution and $\mathrm{AMS}{ }^{14} \mathrm{C}$ dating to reconstruct depositional dynamics. The studied core, recovered from the northern part of the lake, shows a cyclic pattern of organic and mineral matter concentration with cycle durations of 100-400 years. Cyclicity is displayed better in sediments laid down between 9,200 and 5,600 cal BP. Within two time windows (5,600-5,100 cal BP and from 1,200 cal BP to the present), sediment composition changed drastically on account of a high and fluctuating mineral matter content, obviously driven by different factors. Little Ice Age cooling is characterised by the highest proportion of mineral matter, and the Medieval Warm Period is typified by high organic matter content. The cyclic change of organic and mineral matter has been related to climate dynamics, most likely an alternation of wet and dry conditions, changes in the water level of the lake and differences in bioproduction.
\end{abstract}

Keywords: cyclicity, granulometry, radiocarbon dates, loss-on-ignition, lake sediments, climate, Holocene

\section{Introduction}

A cyclic pattern in lacustrine sediments has been found at different localities, and its formation has been explained by various factors (Yu \& Ito, 1999, 2003; Battarbee et al., 2001; Skilbeck et al., 2005; Wu et al., 2009). Studying loss-on-ignition (LOI), magnetic susceptibility (MS), diatoms, $\delta{ }^{13} \mathrm{C}$ and chironomid head capsule abundance in a loch sequence from the Scottish Mountains, Battarbee et al. (2001) identified a quasi-periodicity of c. 200-225 years in organic matter $(\mathrm{OM})$ content and attributed this to changes in lake productivity driven by climate variability. Yu \& Ito (1999, 2003) described a 400year wet-dry cycle in six Great Plain Lake sediment cores (roughly between $45^{\circ}$ and $52^{\circ} \mathrm{N}$, USA) and related dry events to decreased solar activity because cosmogenic isotopes $\left({ }^{14} \mathrm{C},{ }^{10} \mathrm{Be}\right)$ also revealed a periodicity of nearly 400 years (Stuiver \& Braziunas, 1989). The sediment record from a Chinese lake provided evidence of deposition of coarse-grained beds during wet and fine-grained beds during dry climatic conditions, with an approximate 400-year periodicity. This was also related to solar activity (Wu et al., 2009).

Several mires in northwest Europe showed cyclic humification ranging in time from a century to a millennium, triggered by changes in hydrological and climatic conditions (Chambers \& Blackford, 2001; Väliranta et al., 2007), precipitation being the prime controlling factor (Charman et al., 2009). Biological and palaeohydrological records from the Central Estonian Männikjärve bog (585’N, $26^{\circ} 15^{\prime} \mathrm{E}$ ) also documented an alternation of drier and wetter conditions (Sillasoo et al., 2009) over an average of 380 years. Still, Väliranta et al. (2007) mentioned that variations in wetness and dryness often were site specific and weakly linked to climate.

The current investigation includes accelerator mass spectrometry (AMS) ${ }^{14} \mathrm{C}$ determinations, LOI and grain-size distribution analyses to explore the 
link between sedimentary cyclic patterns and climate change with special attention to Lake Veetka (Fig. 1A, B) in the Karula Upland. This had become a subject for concern following the discovery of a cyclic depositional pattern in several small lakes in southern Estonia (Saarse, 2014).

\section{Geological setting}

The Karula Upland in southern Estonia is bordered by a depression in the east and by lowlands in the west. Its mosaic hilly topography was formed during the retreat of the last Weichselian ice sheet and melting of buried ice blocks. The relief comprises glacial and glaciofluvial sediments and, to a lesser extent, glaciolacustrine deposits, the bedrock consisting of Devonian sandstones. Lake Veetka (hereafter Veetka, on some maps also spelt Viitka; 57 $44^{\prime} \mathrm{N}, 2^{\circ} 28^{\prime} \mathrm{E}$ ) in the northwestern part of Karula National Park is a small (3.3 ha), shallow (maximum water depth $5.5 \mathrm{~m}$, on average $3.9 \mathrm{~m}$ ), eutrophic, weakly drained lake at an altitude of
$88 \mathrm{~m}$ above sea level (a.s.l.; Fig. 1B). Similar to numerous others, Veetka is located in the glaciokarst hollow, surrounded by cupolas and hills, consisting mostly of glaciofluvial silty and sandy deposits. It has a small inlet stream from the east and a small outlet towards the south. The water is alkaline $(\mathrm{pH}$ 7.6-7.8) and rich in mineral compounds and organic substances (Mäemets, 1977). Currently, macrophytes Elodea canadensis, Stratiodes aloides, Nyphar luteum, Carex and Phragmites, cover almost the entire lake bottom. Betula-Pinus-Picea groves dominate the east of the lake, with a mire in the south and cultivated land in the western, northern and northeastern part; the lake itself is fringed by a narrow, weedy rim (Fig. 1B).

\section{Material and methods}

In the early spring of 2013, a 1077-cm-long core was taken from the northern part of lake by a 1-m-long Russian peat corer at a site where water depth was $5 \mathrm{~m}$ (Table 1). The topmost $22 \mathrm{~cm}$ of loose
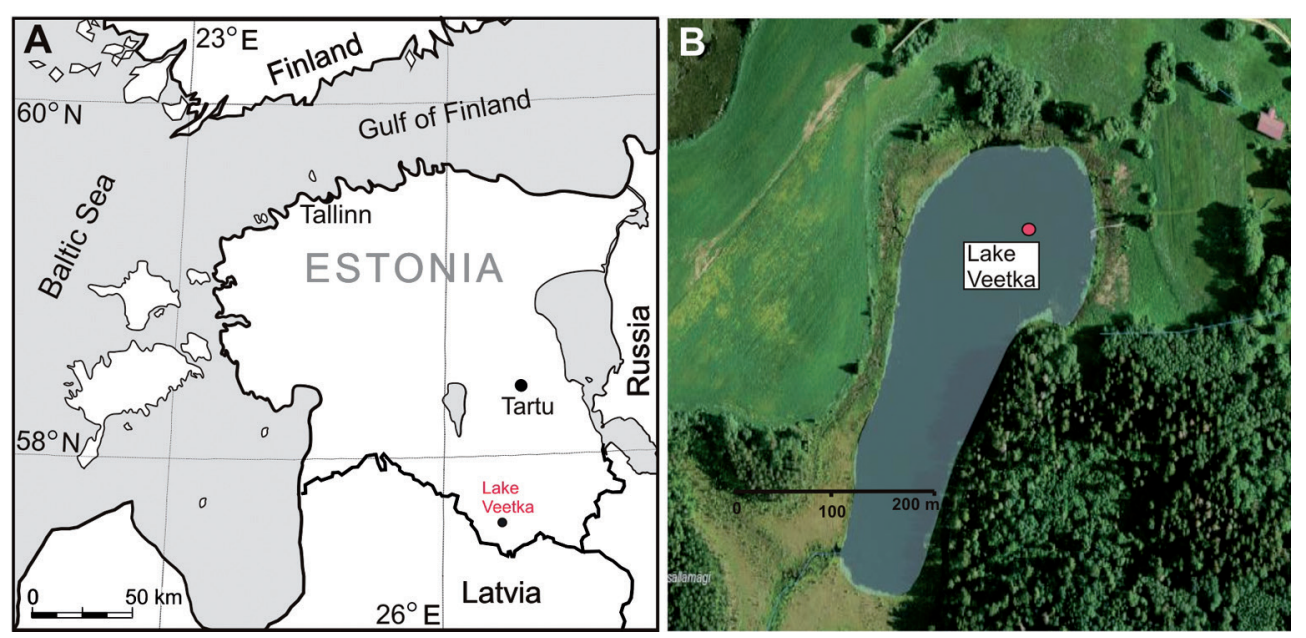

Fig. 1. Location of Lake Veetka (A) and the sampling site, marked by a red dot (B).

Table 1. Lithology of the Lake Veetka sequence.

\begin{tabular}{|c|c|c|}
\hline $\begin{array}{l}\text { Depth below wa- } \\
\text { ter surface }[\mathrm{cm}]\end{array}$ & $\begin{array}{l}\text { Age description } \\
{[\text { cal BP] }}\end{array}$ & \\
\hline $0-500$ & & Water \\
\hline $500-515$ & $1-115$ & Gyttja, silty, loose, black; mineral matter $60-75 \%$ \\
\hline $515-537$ & $115-370$ & Gyttja, silty, dark grey; mineral matter $80-92 \%$ \\
\hline $537-571$ & $370-765$ & Gyttja, silty, dark brown; mineral matter decreasing downsection from 78 to $42 \%$ \\
\hline $571-611$ & $765-1230$ & Gyttja, dark brown; mineral matter $20-40 \%$ \\
\hline $611-779$ & $1230-2500$ & Gyttja, organic rich, dark brown; mineral matter less than $15 \%$ \\
\hline 779-1137 & $2500-5150$ & Gyttja, dark brown; mineral matter $20-30 \%$ \\
\hline $1137-1179$ & $5150-5600$ & Gyttja, silty, dark brown; rich in mineral matter, $38-72 \%$ \\
\hline 1179-1577 & $5600-10500$ & $\begin{array}{l}\text { Gyttja, blackish brown, containing vivianite; mineral matter increasing down- } \\
\text { section from } 30 \text { to } 60 \% \text {; clearly rhythmic sedimentation }\end{array}$ \\
\hline
\end{tabular}


Table 2. AMS ${ }^{14} \mathrm{C}$ radiocarbon dates for Lake Veetka.

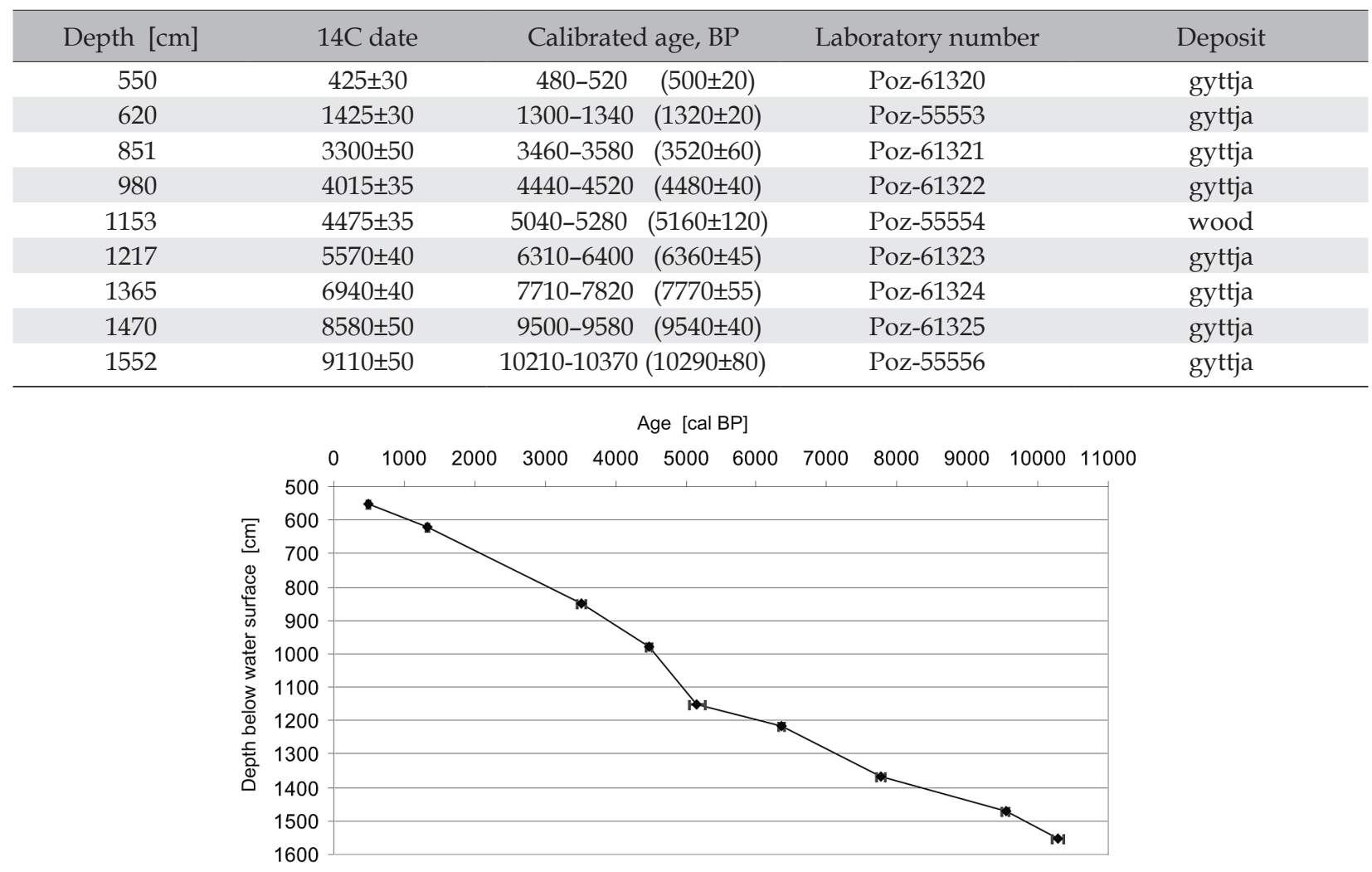

Fig. 2. An age-depth model for the Lake Veetka core.

sediment was obtained by a Willner-type sampler. Cores were described in the field, photographed, wrapped in plastic half-tubes and transported to the laboratory for future analysis and documentation.

The AMS dates from eight bulk gyttja and one woody piece were determined in the Poznań Radiocarbon Laboratory (Table 2; Fig. 2). The chronology of the core studied is based on the calibration of radiocarbon dates using the IntCal13 program (Reimer et al., 2013). In the present study, calibrated ages (cal BP relative to AD 1950) at one sigma are employed (Fig. 2; Table 2).

To quantify the organic, carbonate and mineral matter content, LOI analysis at $525{ }^{\circ} \mathrm{C}$ and $900{ }^{\circ} \mathrm{C}$ was performed continuously for 2-cm-thick samples (Fig. 3). The amount of residue containing clastic material and biogenic silica was described as mineral matter and counted up against the sum of organic and carbonate compounds. An LOI diagram was plotted with the TILIA and TILIA.Graph programs (Grimm, 2011). Grain size distribution was studied in seven intervals of the core with the help of the Partica laser analyser LA-950V2. The laser analyser used measured grain size in the range of 0.011-3000 $\mu \mathrm{m}$ and distinguished 93 magnitudes. Organic matter (OM) was removed by wet oxidation with $30 \%$ hydrogen peroxide and carbonates by $10 \% \mathrm{HCl}$ (Vaasma, 2008). Grain size classification follows the Udden-Wentworth scale with the limit between clay and silt fraction at $1.95 \mu \mathrm{m}$, between sand and silt fraction at $62.5 \mu \mathrm{m}$, between sand and pebble (gravel) at $2 \mathrm{~mm}$ (Last, 2001).

\section{Results}

The core collected from the northern part of Veetka extends back in time to $10,500 \mathrm{cal} \mathrm{BP}$, and sediments accumulated steadily because radiocarbon dates showed a good stratigraphic order (Fig. 2). The sedimentation rate was, on average, $1.01 \mathrm{~mm}$ $\mathrm{yr}^{-1}$, surpassing twofold the rate of gyttja $(0.5 \mathrm{~mm}$ $\left.\mathrm{yr}^{-1}\right)$ for Estonian lakes (Saarse, 1994), and the average $\left(0.65 \mathrm{~mm} \mathrm{yr}^{-1}\right)$ in temperate lakes in the USA (Webb \&Webb III, 1988).

The alternation of gyttja and silty gyttja allowed five lithostratigraphical units to be distinguished, two of which (Ve-2 and Ve-5) were highly minerogenic (Fig. 3). The basal unit, Ve-1 (1577-1181 $\mathrm{cm} ; 10,500-5,680 \mathrm{cal} \mathrm{BP}$ ) is composed of gyttja in which mineral matter decreased upsection from $60 \%$ to $20 \%$ and OM increased from $35 \%$ to $75 \%$. The carbonate content was less than $8 \%$. Regularly changeable $\mathrm{OM}$ and mineral matter formed a cy- 


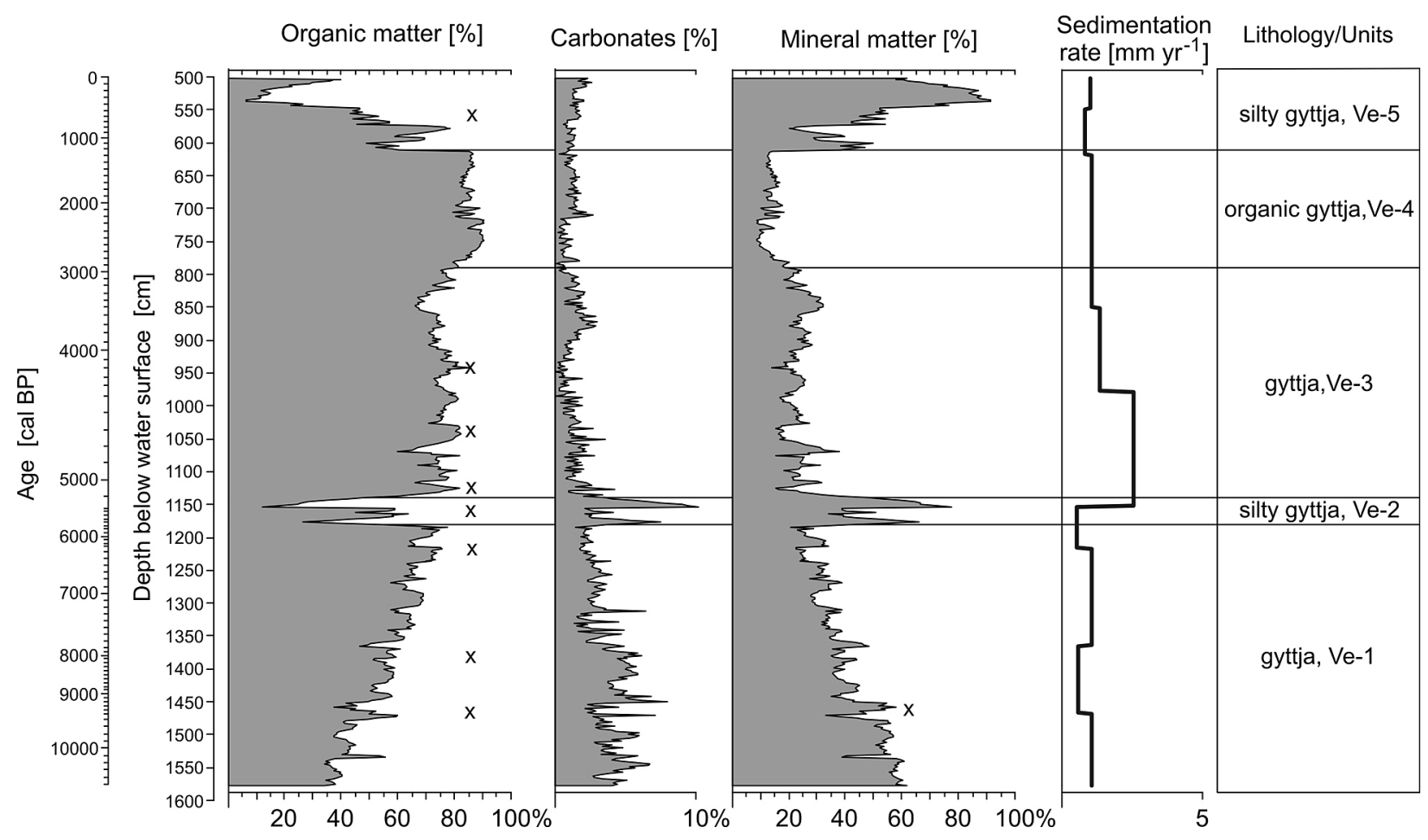

Fig. 3. Lithology, loss-on-ignition and sedimentation rate results for the Veetka sequence; the position of cycles for which grain size analyses have been carried out is marked by $\mathrm{X}$.

clic pattern averaging 200-400 years. For this unit, sediment grain-size was studied in three different cycles: two OM-rich cycles and one rich in mineral matter (Fig. 3, marked by $x$ ). In the mineral-rich cycle between 1467 and $1449 \mathrm{~cm}(9,490-9,180 \mathrm{cal} \mathrm{BP})$ mineral matter attained $59 \%$ at $1461 \mathrm{~cm}(9,390 \mathrm{cal}$ $\mathrm{BP}$ ) that surpassed $\mathrm{OM}$ at $22 \%$ (Fig. 4A). Medium and coarse silt prevailed; the sand content was less than $6 \%$, but increased towards the upper limit of the cycle and its distribution mostly resembled that of carbonates. Grain size is clayey in nature in the median part of the cycle (Fig. 4A). This cycle lasted 310 years, the sedimentation rate having been 0.58 $\mathrm{mm} \mathrm{yr}^{-1}$.

OM showed a clear cycle at $1387-1365 \mathrm{~cm}(8,140-$ $7,760 \mathrm{cal} \mathrm{BP}$ ), which was the most sandy (reaching $60 \%$ ) among the cycles studied (Fig. 4B). At the start of the cycle, the OM content was rather low $(46 \%)$, but this increased rapidly to $60 \%$. In view of the fact the carbonate content was stable and low (less than $7 \%$ ), the mineral matter curve mirrored that for $\mathrm{OM}$ and was very close to the silt fraction curve (Fig. 4B). The clay fraction was missing altogether. Due to the prevalence of the sand fraction the mean grain size was considerably coarser than that of the first cycle. In spite of the coarse grain size in comparison with the first cycle, mineral matter even decreased (Fig. $4 \mathrm{~A}, \mathrm{~B})$. This cycle lasted 380 years, with an average sedimentation rate equal to the first cycle studied $\left(0.58 \mathrm{~mm} \mathrm{yr}^{-1}\right)$.

The grain size composition of the third cycle, between 1241 and $1213 \mathrm{~cm}(6,580-6,280 \mathrm{cal} \mathrm{BP})$ was fairly comparable with that for the first cycle (Fig. $4 \mathrm{~A})$, with a prevalence of medium and coarse silt, but differed by a low clay fraction content (Fig. 4C). At the onset and the end of the cycle, the OM was $64 \%$ and, accordingly, the mineral matter $34 \%$. In this cycle both mineral matter and sand fraction have diminished in comparison with the previous cycle (Fig. 4D, E). The third cycle lasted 300 years, approximately matching the first cycle, but the sedimentation rate had almost doubled, at $0.93 \mathrm{~mm} \mathrm{yr}^{-1}$.

The second unit Ve-2 (1181-1139 cm; 5,680-5,100 cal BP) differed by an alternation of gyttja with two mineral-rich, slightly carbonaceous layers (Fig. 3); the uppermost layer contained woody pieces dated at 5,160 cal BP (Table 2). In a mineral-rich layer between 1155 and $1139 \mathrm{~cm}$ (5,190-5,100 cal BP; Fig. 4D), the OM content constantly and rapidly decreased from 43 to $12 \%$ and grain size became more silty with small addition of clay. In the organic layer, comprising $17 \mathrm{~cm}$ between $1172-1155 \mathrm{~cm}$ and representing the time from 5,510 to 5,190 cal $\mathrm{BP}, \mathrm{OM}$ reached $60 \%$, but grain size was very variable (Fig. 4D). In the lowermost mineral-rich layer $(1181-1172 \mathrm{~cm})$, the mineral matter shows a clear peak which roughly coincides with the silt peak 
(Fig. 4D). Altogether, this unit lasted 580 years, during which beds rich in mineral matter (i.e., the first and third) accumulated over 90 and 170 years, respectively, and the organic-rich bed between them accumulated over 320 years. The sedimentation rate was $1.78,0.53$ and $0.53 \mathrm{~mm} \mathrm{yr}^{-1}$, respectively.

The third unit, Ve-3 (1139-790 cm), comprised gyttja (OM 60-82\%), which was deposited between 5,100 and 2,950 cal BP. The sedimentation rate decreased upwards from 2.5 to $1.03 \mathrm{~mm} \mathrm{yr}^{-1}$. Eight cycles could be distinguished, with total range of 270 years, being irregular and short (on average $120 \mathrm{yr}$ ) between 5,120 and 4,750 cal BP. In one such short cycle (1091 and $1069 \mathrm{~cm} ; 4,910-4,830 \mathrm{cal} \mathrm{BP})$, covering only 80 years, grain size was studied (Fig. 4E). The silt fraction predominates, sand and clay fractions being rare (Fig. 4E). Both the LOI and grain size records were fairly regular. Grain size of the longer cycle between 959 and 931 (4,320-4,110 cal $\mathrm{BP})$ differed from that of the short cycle in containing more sand and lasting 210 years (Fig. 4F), but comprising c. 5\% less mineral matter.

Unit Ve-4 covered the core depth 790-610 cm and time slices of 2,950-1,200 cal BP (Fig. 3). It showed the highest $\mathrm{OM}$ content and lowest percentage of mineral matter, but a clear rhythmic signal is absent (Fig. 3). The sedimentation rate was rather rapid: $1.03 \mathrm{~mm} \mathrm{yr}^{-1}$.

The topmost unit, Ve-5 (610-500 cm; from 1,200 cal BP to the present), is similar to unit Ve-2 in revealing variable LOI, and especially high, albeit unstable, mineral matter with two well-developed peaks. The carbonate content was equal and did not correlate with the mineral matter peaks as in unit Ve-2 (Fig. 3). The lowermost peak of mineral matter was centred at $601 \mathrm{~cm}$ (approximately 1,100 cal BP); the highest mineral matter peak was at $535 \mathrm{~cm} \mathrm{(340}$ cal BP). This was separated from the lowest by an $\mathrm{OM}$ peak at $579 \mathrm{~cm}$ (830 cal BP). The OM content varied drastically throughout this unit, from 6 to $77 \%$. As the carbonate content was low, the mineral matter and OM graphs showed opposite trends (Fig. 3). The grain size distribution record covered the entire unit and was dominated by silt; the sand fraction fluctuated between 4 and $31 \%$, and the clay fraction between 0.6 and $14 \%$ (Fig. 4G). The average sedimentation rate remained below $1 \mathrm{~mm} \mathrm{yr}^{-1}$ $\left(0.92 \mathrm{~mm} \mathrm{yr}^{-1}\right)$. In this unit, five cycles with an average range of 240 years were identified (Fig. 4G). In the topmost cycle, $521-500 \mathrm{~cm}$ to $210 \mathrm{cal} \mathrm{BP}$, the

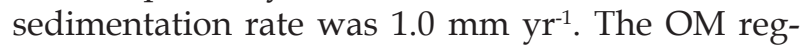
ularly decreased and the mineral matter increased by $30 \%$, but grain-size composition remained fairly stable. In the next cycle (547-521 cm, 460-210 cal BP,

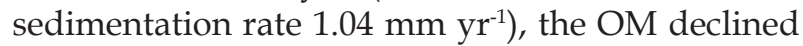

to $539 \mathrm{~cm}$ and then abruptly increased to $46 \%$ (Fig. $4 G)$. In grain-size distribution, the sand fraction shows a peak at $30 \%$ (Fig. 4G). This is the sole cycle studied in which the high mineral matter content coincides with an elevated sand fraction; yet, their peaks do not overlap. From 571 to $547 \mathrm{~cm}$ (740-460 cal $\mathrm{BP}$, sedimentation rate $0.86 \mathrm{~mm} \mathrm{yr}^{-1}$ ) the $\mathrm{OM}$ increased in a stepwise manner, but grain-size distribution remained fairly identical. On this accumulation period followed an interval (1,200-740 cal BP) during which both the LOI and grain size changed remarkably. During this time window, two cycles have been distinguished with the boundary between them at $591 \mathrm{~cm}$ (980 cal BP) and sedimentation rate accordingly 0.83 and $0.86 \mathrm{~mm} \mathrm{yr}^{-1}$.

\section{Discussion}

Sedimentation in Lake Veetka is of special interest on account of cyclic OM and mineral matter deposition. This pattern is best seen between 1470$1180 \mathrm{~cm}(9,200-5,600 \mathrm{cal} \mathrm{BP})$, where nine cycles with an average duration of $c .400$ years were identified (Fig. 3). This portion of sediment was deposited mostly during the Holocene Thermal Maximum (HTM).

The main driving factor of the cyclic sedimentation during the early and mid-Holocene (boundary at 8,200; Walker et al., 2012) in Lake Veetka is not clear. It could be that cyclic sedimentation is associated with an alternation of wet and dry climate conditions that determined the hydrological variations in the lake and had an impact on primary production. In order to test this hypothesis, sediment LOI and grain size results were compared with different proxies from Estonia and neighbouring areas.

The globally distributed palaeoclimatic record reveals six periods during which climate changed rapidly: 9,000-8,000; 6,000-5,000;4,200-3,800; 3,5002,500; 1,200-1,000 and 600-150 cal BP (Mayewski et al., 2004), underpinned by multiple driving factors. LOI results from the Veetka core show a high mineral matter between 10,500 and 9,200 cal BP, which might be indicative of a cooler climate, as deduced from oxygen isotope data of Lake Äntu Sinijärv $\left(59^{\circ} 03^{`} \mathrm{~N}, 2^{\circ} 14^{`} \mathrm{E}\right.$, northern Estonia; Laumets et al., 2014) and Lake Igelsjön ( $58^{\circ} 28^{\prime} \mathrm{N}, 13^{\circ} 44^{\prime} \mathrm{E}$, southern Sweden; Hammarlund et al., 2003). A clear peak in mineral matter between 9,400 and 9,200 cal BP (Fig. 3) coincides with a temperature drop in the northern Baltic region, as inferred from pollen data (Heikkilä \& Seppä, 2010; Veski et al., 2014). At the same time, a distinct lowering of water levels was recorded for several lakes in southern Sweden (Digerfeldt, 1988) 

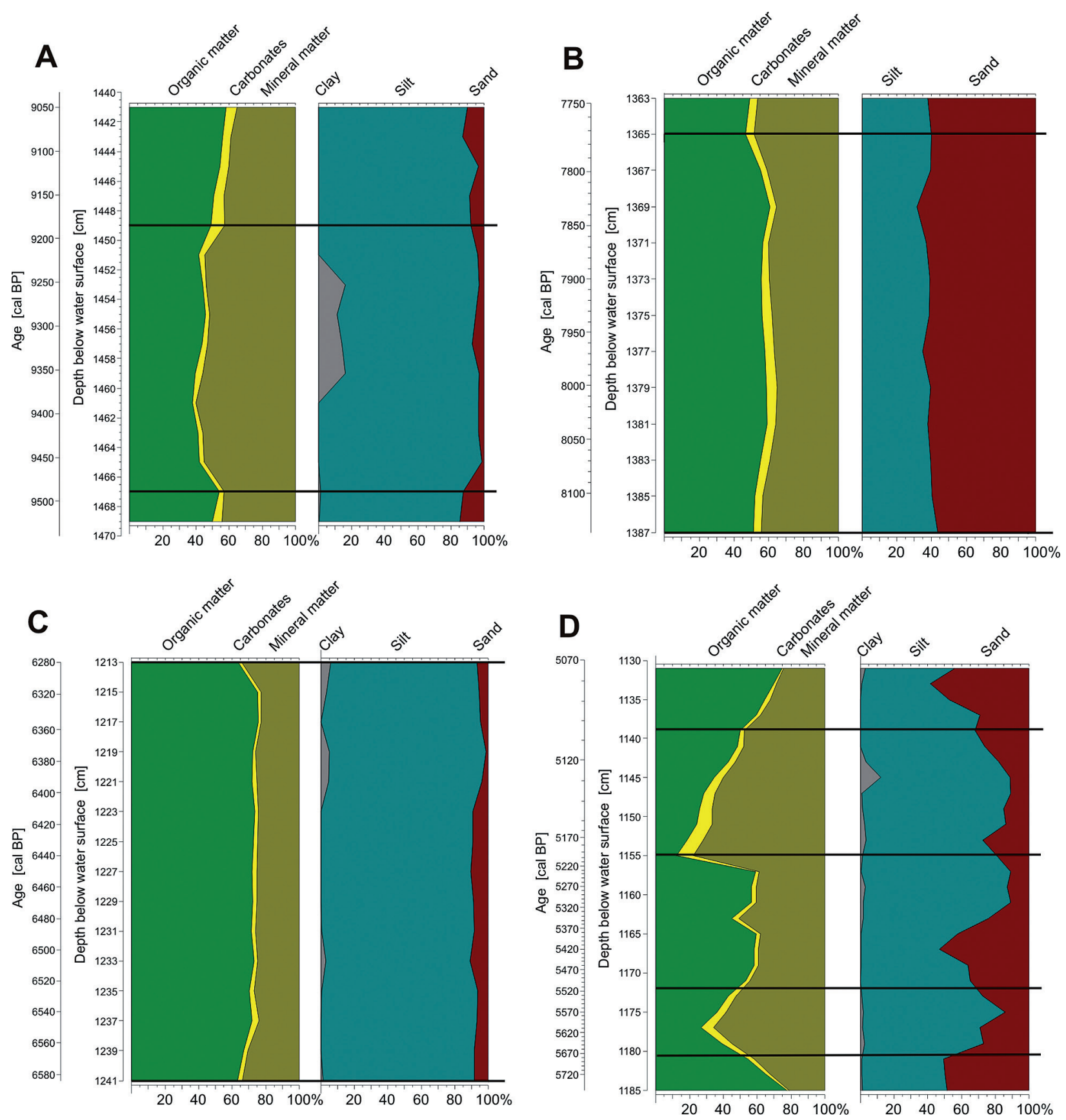

Fig. 4. Grain size distribution and comparison with LOI results at core depths of 1469-1441 cm (A); 1387-1363 cm (B); 1241-1213 cm (C); 1185-1131 cm (D); 1093-1069 cm (E); 969-931 cm (F); 611-501 cm (G). Limits of cycles are marked by horizontal lines.

and Estonia (Saarse et al., 1995), indicating a drier climate.

Pollen records and climate reconstructions from southern Estonia and Latvia confirm that a prominent warming phase started approximately at 9,000 cal BP (Niinemets \& Saarse, 2006; Heikkilä \& Seppä, 2010), which matches a progressive decline in mineral matter and an increase of $\mathrm{OM}$ in the Veetka core (Fig. 3). A temperature drop at 8,200, triggered by an outburst from Lake Agassiz that led to a glob- ally recognised cooling (Alley et al., 1997), is not clearly reflected in the Veetka LOI graph (Fig. 3), although this cooling was registered in two pollen records from southern Estonia, but not in the LOI data (Veski et al., 2004; Niinemets \& Saarse, 2007b).

Between 9,200 and 5,600 cal BP, the OM and mineral matter content changed rhythmically, albeit not regularly at the same magnitude (Fig. 3). The oxygen isotope curve from Lake Äntu Sinijärv also changed steadily, documenting nine cycles be- 

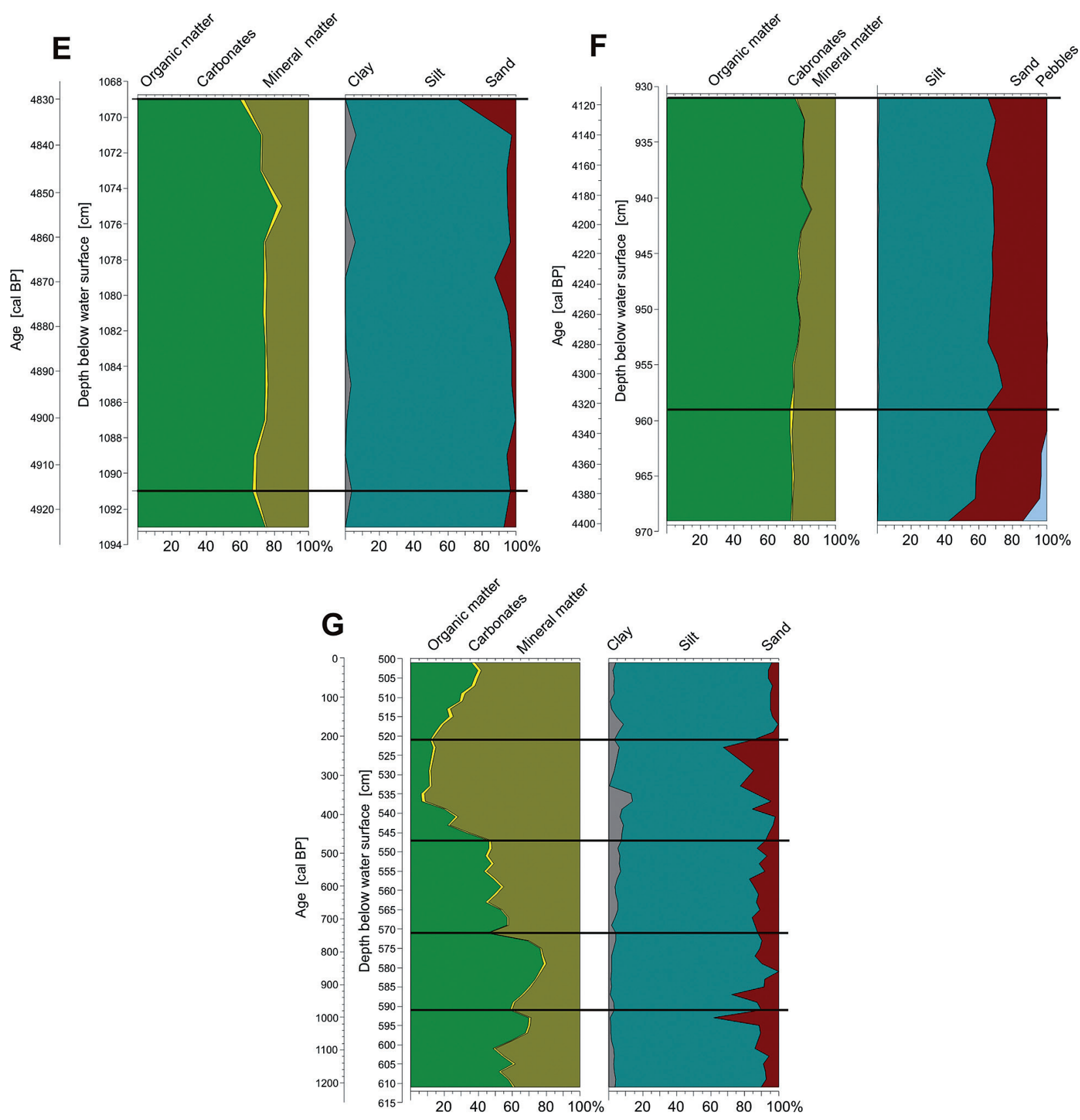

Fig. 4. continued.

tween 9,000 and 5,800 cal BP (Laumets et al., 2014). This period (roughly HTM) is characterised by a warm and rather dry climate (Seppä et al., 2009; Luoto et al., 2012). Glaciers retreated in the Alps, which was explained by solar activity and high summer insolation (Simonneau et al., 2014). Lake level reconstruction showed a rise between 9,000 and 7,500 cal BP (Digerfeldt, 1988). The predominance of the sand fraction in the studied portion of the sediment between 8,100-7,760 cal BP could have been driven by increased runoff into the lake and transportation of coarser-grained material (Fig. 4B). Due to increased dryness (Seppä et al., 2009) lake level started to drop at 7,500 cal BP (Digerfeldt, 1988; Sohar \& Kalm, 2008). The rhythmic deposition of OM and mineral matter in Veetka and other lakes in southern Estonia was probably caused by changes in lake productivity, driven by thermal variability and changes in precipitation as the main controlling factors. 
Between 5,700 and 5,100 cal BP mineral matter and carbonate percentages sharply increased (Fig. 3 ) and the sediment became more sandy in comparison with the time interval between 6,600 and 6,300 cal BP (Figs 4C, D). Lake level lowering and catchment erosion caused a rise of washed-in carbonates, consistent with a cooling between 5,800 and 5,100 cal BP, as recorded from different parts of Europe and linked to the changing circulation pattern (Seppä et al., 2009). Glacier advance in Scandinavia and the Alps (Magny \& Haas, 2004; Nesje, 2009), culminating approximately at 5,300 cal BP (Denton \& Karlén, 1973), also provides evidence of climate deterioration. However, climate alone can barely explain such a drastic change in LOI and grain size data as recorded in Veetka (Fig. 4D). The sand fraction and mineral matter show a changing, but not uniform trend, obviously as a result of fluctuating lake level and catchment erosion (Digerfeldt, 1988; Sohar \& Kalm, 2008). As for pollen profiles, a sharp decline in Tilia and an increase in Picea pollen at 5,300 cal BP also support climate cooling (Niinemets \& Saarse, 2006). Therefore, the LOI signal in Veetka was probably controlled by the hydrological balance in the lake, by catchment erosion and by bioproduction driven by climatic variability.

The termination of the HTM is dated roughly at 5,200 cal BP; however, this was not a synchronous event across Europe (e.g., Hammarlund et al., 2003; Seppä \& Poska, 2004; Galka \& Apolinarska, 2014). In northeast Europe it was detected up to $4,000 \mathrm{cal}$ BP (Heikkilä \& Seppä, 2010), and up to 4,500 cal BP in Estonia (Seppä \& Poska, 2004). Subsequent climate deterioration was terminated by brief warming events and alternating wetter and drier climate conditions (Sillasoo et al., 2007, 2009; Väliranta et al., 2007).

Between 5,100 and 3,500 cal BP, a cyclic sedimentation pattern occurred, but its pacing and character differed from the cyclic patterns between 9,200 and 5,600 cal BP (Fig. 3). Nevertheless, eight cycles could be distinguished with an average duration of 200 years and an accumulation rate of $1.81 \mathrm{~mm} \mathrm{yr}^{-1}$. This interval coincides with an annual temperature decrease in the Baltic region (Heikkilä \& Seppä, 2003, 2010; Seppä \& Poska, 2004), fluctuating lake levels (Digerfeldt, 1988; Saarse et al., 1995) and the replacement of warm-tolerant tree taxa by cold-tolerant species (Niinemets \& Saarse, 2006, 2008; Reitalu et al., 2013). Increased wetness, in response to a lower summer temperature, in southern Sweden started approximately at 4,000 cal BP (this date was proposed for the middle-upper Holocene boundary; Walker et al., 2012) and was explained by shifts in the atmospheric circulation pattern (Jessen et al., 2005). A decrease in $O M$ and slight increase in mineral compounds in Veetka also started approximately at 4,000 cal BP and terminated at c. 3,500 cal BP (Fig. 3), suggesting a rise in humidity.

Since 3,500 cal BP, OM considerably increased, reaching a maximum between 2,500 and 2,100 cal $\mathrm{BP}$, and mineral matter dropped to a minimum (Fig. 3). Between 3,500 and 1,200 cal BP, several alternating wet and dry periods can be differentiated on the basis of plant macrofossils and testate amoebae records from Estonia and Finland (Sillasoo et al., 2009; Väliranda et al., 2012), thus reflecting climate variability. A clear cyclic pattern in the Veetka sediment core is absent, probably obscured by the very high OM content and/or human impact. A cooling event detected in several parts of Europe (e.g., Matrin-Puertas et al., 2012), consistent with an increase in ice rafted debris in the North Atlantic approximately at 2,800 cal BP (Bond et al., 2001), cannot be traced in the Veetka (Fig. 3) and other LOI graphs from southern Estonia (Niinemets \& Saarse, $2006,2007 a, b)$. It seems that changes in LOI results were rather site specific and influenced by the hydrological regime of the lake and by bioproduction.

Changes in sediment composition between 1200 and the present were mostly induced by human activities and climate, such as the Medieval Warm Period around AD 950-1350 and climate deterioration during the Little Ice Age (LIA) between AD 1350 and 1850 (Wanner et al., 2008). LIA was not an isolated event, but widespread climatic deterioration and the coldest phase in the millennium-scale cycle most clearly expressed in the North Atlantic region (Denton \& Karlén, 1973).

The sharp decline of OM in the Veetka core at 1,200 cal BP and elevated mineral matter (Fig. 3) resulted from the expansion of land cultivation and disafforestation as crop farming became the predominant means of subsistence (Väli et al., 2014). This promoted soil erosion in a highly mosaic landscape and an influx of mineral matter into the lake. Yet carbonate content remained almost stable, obviously as a result of the humid climate, which caused leaching of carbonates from the upper part of soil profiles and their acidification.

Based on drastic changes in LOI results, five sedimentological cycles have been distinguished (Fig. 4G). The lowermost cycle covers the interval $1,200-980$ cal BP $(611-591 \mathrm{~cm})$ is characterised by changeable $\mathrm{OM}$ and mineral matter percentages, resulting primarily from the nature of agricultural practice and climatic conditions. As fire cultivation was the principal land-use practice, soils rapidly became depleted in nutrients and fields were abundant and left to be overgrown by bushes (Jääts et 
al., 2010). Climatic warming and increased nutrient supply into the lake that led to increased bioproduction during the Middle Ages probably were the main reasons why OM accumulation in the lake increased during the cycle between 980 and $740 \mathrm{cal}$ BP (591-571 cm; Fig. 4G). The next sharp change in sediment composition, between 740 and 460 cal BP $(571-547 \mathrm{~cm})$ coincides with the German crusade invasion into Estonia, which introduced serfage and a lifestyle change among local people. A rise in population and export of agricultural products resulted in the need for new arable land, leading to largescale woodland clearing and an increased influx of mineral matter into the lake (Fig. 4G). High percentages of mineral matter between 460 and $210 \mathrm{cal} \mathrm{BP}$ $(547-521 \mathrm{~cm})$ are coincident with the coldest period of the LIA (e.g., Tarand \& Nordli, 2001; Tarand et al., 2013; Luoto et al., 2008) and with a high influx of cereal pollen, indicating increased agricultural activities (Niinemets \& Saarse, 2007a, b). Utilisation of new agricultural techniques and the expansion of stock farming as the main source of fertiliser mitigated the need for new land and reduced soil erosion since $210 \mathrm{cal} \mathrm{BP}$ (521 cm; Fig. 4G). Previous (Saarse \& Niinemets, 2007) and current results indicate that climatic deterioration during the LIA favoured a mineral matter flux into the sediment basin, whereas the Medieval Warm Period promoted bioproduction and organic deposition, and human impact was unable to obscure this trend, at least in southern Estonia. However, a clear correlation between grain size and mineral matter is not seen.

\section{Conclusions}

Cyclic sedimentation of organic and mineral matter is a characteristic pattern in Lake Veetka and several other lakes in southern Estonia. Cyclicity is observed better in the lowermost portion of sediment, where human impact was absent or extremely low. The best cyclicity was recorded between 9,200 and 5,600 and roughly coincides with the HTM, which is characterised by a stable or slightly changing climate. Nevertheless, the cyclicity was not strictly periodic, but changed between 200 and 400 years, probably indicating a climate in which brief warming was punctuated by colder phases. The most drastic change in the LOI data coincides with regionally altered climate systems, at approximately 9,000-9,300; 5,600-5,200 and during the last 1,200 years (Heikkilä \& Seppä, 2010; Seppä et al., 2009; Veski et al., 2014). However, several local driving forces, such as lake level fluctuation, soil erosion, bioproduction and human impact, also have an impact on the sediment composition and cyclic pattern.

\section{Acknowledgements}

I wish to thank Atko Heinsalu and Siim Veski, for assistance in the field. Anonymous referees are acknowledged for critical remarks and suggestions. I also appreciate Elsevier language editing team for correcting English. This study was supported by institutional research funding IUT 1-8 and ESF Grant 9031.

\section{References}

Alley, R.B., Mayewski, P.A., Sowers, T., Taylor, K.C. \& Clark, P.U., 1997. Holocene climate instability: a prominent widespread event $8200 \mathrm{yr}$ ago. Geology 25, 483-486.

Battarbee, R.W., Cameron, N.G., Golding, P., Brooks, S.J., Switsur, R., Harkness, D., Appleby, P., Oldfield, F., Thompson, R., Monteith, D.T. \& McGovern, A., 2001. Evidence for Holocene climate variability from the sediments of a Scottish remote mountain lake. Journal of Quaternary Science 16, 4, 339-346.

Bond, G., Kromer, B., Beer, J., Muscheler, R., Evans, M.N., Showers, W., Hoffmann, S., Lotti-Bond, R., Hajdas, I. \& Bonani, G., 2001. Persistent solar influence on North Atlantic climate during the Holocene. Science 278, 1257-1266.

Chambers, F.M. \& Blackford, J.J., 2001. Mid- and Late-Holocene climate changes: a test of periodicity and solar forcing in proxy-climate data from blanket peat bogs. Journal of Quaternary Science 16, 4, 329-389.

Charman, D.J., Barber, K.E., Blaauw, M., Langdon, P.G., Mauquoy, D., Daley, T.J., Hughes, P.D.M. \& Karofeld, E., 2009. Climate drivers for peatland palaeoclimate records. Quaternary Science Reviews 28, 1811-1819.

Denton, G.H. \& Karlén, W., 1973. Holocene climate variations - their pattern and possible cause. Quaternary Research 3, 155-205.

Digerfeldt, G., 1988. Reconstruction and regional correlation of Holocene lake-level fluctuations in Lake Bysjön, South Sweden. Boreas 17, 165-182.

Gałka, M. \& Apolinarska, K., 2014. Climate change, vegetation development, and lake level fluctuations in Lake Purwin (NE Poland) during the last 8600 cal. BP based on a high-resolution plant macrofossil record and stable isotope data $\left(\delta^{13} \mathrm{C}\right.$ and $\left.\delta^{18} \mathrm{O}\right)$. Quaternary International 328-329, 213-225.

Grimm, E., 2011. Tilia software v. 1.7.16. Illinois State Museum. Research and Collection Center, Springfield.

Hammarlund, D., Björck, S., Buchardt, B., Israelson, C. \& Thomsen C.T., 2003. Rapid hydrological changes during the Holocene revealed by stable isotope records of lacustrine carbonates from Lake Igelsjön, southern Sweden. Quaternary Science Reviews 22, 353-370. 
Heikkilä, M. \& Seppä, H., 2003. A 11,000 yr palaeotemperature reconstruction from the southern boreal zone in Finland. Quaternary Science Reviews 22, 541-554.

Heikkilä, M. \& Seppä, H., 2010. Holocene climate dynamics in Latvia, eastern Baltic region: a pollen-based summer temperature reconstruction and regional comparison. Boreas 39, 705-719.

Jessen, C.A., Rundgren, M., Björck, S. \& Hammarlund, D., 2005. Abrupt climatic changes and an unstable transition into a late Holocene Thermal Decline: a multiproxy lacustrine record from southern Sweden. Journal of Quaternary Science 20, 349-362.

Jääts, L., Kihno, K., Tomson, P. \& Konsa, M., 2010. Tracing fire cultivation in Estonia. Forestry Studies 53, 53-63.

Last, W.M., 2001. Textural analysis of lake sediments. [In:] W.M. Last \& J.P. Smol (Eds.): Tracking Environmental Change Using Lake Sediments. Volume 2: Physical and Geochemical Methods. Kluwer Academic Publishers, Dordrecht, 41-81.

Laumets, L., Kalm, V., Poska, A., Kele, S., Lasberg, K. \& Amon, L., 2014. Palaeoclimate inferred from $\delta^{18} \mathrm{O}$ and palaeobotanical indicators in freshwater tufa of Lake Äntu Sinijärv, Estonia. Journal of Paleolimnology 51, 99-111.

Luoto, T., Nevalainen, L., Kauppila, T., Tammelin, M. \& Sarmaja-Korjonen, K., 2012. Diatom-inferred total phosphorus from dystrophic Lake Arapisto, Finland, in relation to Holocene paleoclimate. Quaternary Research 78, 248-255.

Luoto, T., Nevalainen, L. \& Sarmaja-Korjonen, K., 2008. Multiproxy evidence for the "Little Ice Age" from Lake Hampträsk, Southern Finland. Journal Paleolimnology 40, 1097-1113.

Magny, M. \& Haas, J.-N., 2004. A major widespread climatic change around $5300 \mathrm{cal}$. yr BP at the time of the Alpine Iceman. Journal of Quaternary Science 19, 423-430.

Martin-Puertas, C., Matthes, K., Brauer, A., Muscheler, R., Hansen, F., Petrick, C., Aldahan, A., Possnert, G. \& van Geel, B., 2012. Regional atmospheric circulation shifts induced by grand solar minimum. Nature Geoscience 5. Letters. DOI: 10.1038/NGEO1460.

Mayewski, P.A., Rohlin, E.E., Stager, J.C., Karlén, W., Maasch, K.A., Meeker, L.D., Meyerson, E.A., Gasse, F., van Kreveld, S., Holmgren, K., Lee-Thorp, J., Rosqvist, G., Rack, F., Staubwasser, M., Schneider, R.R. \& Steig, E.J., 2004. Holocene climate variability. Quaternary Research 62, 243-255.

Mäemets, A., 1977. Eesti NSV järved ja nende kaitse [Lakes of the Estonian S.S.R. and their protection]. Valgus, Tallinn, 263 pp. [in Estonian with English summary].

Nesje, A., 2009. Latest Pleistocene and Holocene alpine glacier fluctuations in Scandinavia. Quaternary Science Reviews 28, 2119-2136.

Niinemets, E. \& Saarse, L., 2006. Holocene forest dynamics and human impact in southeastern Estonia. Vegetation History and Archaeobotany 16, 1-13.

Niinemets, E. \& Saarse, L., 2007a. Fine-resolution pollen-based evidence of farming and forest development, south-eastern Estonia. Polish Journal of Ecology $55,283-296$.
Niinemets, E. \& Saarse, L., 2007b. Mid- and late-Holocene land-use changes inferred from pollen records, in a south-eastern Estonian upland areas. Review of Palaeobotany \& Palynology 146, 51-73.

Niinemets, E., \& Saarse, L., 2009. Holocene vegetation and land-use dynamics of south-eastern Estonia. Quaternary International 207, 104-116.

Reitalu, T., Seppä, H., Sugita, S., Kangur, M., Koff, T., Avel, E., Kihno, K., Vassiljev, J., Renssen, H., Hammarlund, D., Heikkila, M., Saarse, L., Poska, A., \& Veski, S., 2013. Long-term drivers of forest composition in a boreonemoral region: the relative importance of climate and human impact. Journal of Biogeography 40, 1524-1534.

Reimer, P.J., Bard, E., Bayliss, A., Beck, J.W., Blackwell, P.G., Bronk Ramsey, C., Buck, C.E., Cheng, H., Edwards, R.L., Friedrich, M., Groots, P.M., Guilderson, T.P., Haflidason, H., Hajdas, I., Hatte, C., Heaton, T.J., Hoffmann, D.L., Hogg, A.G., Hughen, K.A., Kaiser, K.F., Kromer, B., Manning, S.W., Niu, M., Reimer, R.W., Richards, D.A., Scott, E.M., Southon, J.R., Turney, C.S.M. \& van der Plicht, J., 2013. IntCal13 and Marine13 radiocarbon age calibration curves, 0-50,000 years cal BP. Radiocarbon 55, 4, 1869-1887.

Saarse, L., 1994. Bottom deposits of small Estonian lakes. Estonian Academy of Sciences, Institute of Geology, Tallinn, 230 pp. [in Russian with English summary].

Saarse, L. 2014. Cyclic sedimentation pattern in Lake Veetka, SE Estonia. [In:] V. Zelčs \& M. Nartišs (Eds): Late Quaternary terrestrial processes, sediments and history: from glacial to postglacial environments. University of Latvia, Riga, 133-135.

Saarse, L., Heinsalu, A. \& Veski, S., 1995. Palaeoclimatic interpretation of the Holocene litho- and biostratigraphic proxy data from Estonia. [In:] Proceedings of the SILMU Conference. Publications of the Academy of Finland, Helsinki, 102-105.

Saarse, L. \& Niinemets, E., 2007. Environmental changes in SE Estonia during the last 700 years. Boreal Environmental Research 12, 611-621.

Seppä, H., Bjune, A.E., Telford, R.J., Birks, H.J.B. \& Veski, S., 2009. Last nine-thousand years of temperature variability in Northern Europe. Climate of the Past 5, 523-535.

Seppä, H. \& Poska, A., 2004. Holocene annual mean temperature changes in Estonia and their relationship to solar insolation and atmospheric circulation patterns. Quaternary Research 61, 22-31.

Sillasoo, Ü., Mauquoy, D., Blundell, A., Charman, D., Blaauw, M., Daniell, J.R.G., Toms, P., Newberry, J., Chambers, F.M. \& Karofeld, E., 2007. Peat multi-proxy data from Männikjärve bog as indicators of Late Holocene climate changes in Estonia. Boreas 36, 20-37.

Sillasoo, Ü., Poska, A., Seppä, H., Blaauw, M. \& Chambers, F.M., 2009. Linking past cultural developments to palaeoenvironmental changes in Estonia. Vegetation History and Archaeobotany 18, 315-327.

Simonneau, A., Chapron, E., Garçon, M. Winiarski, T., Graz, Y., Chauvel, C., Debret, M., Motelica-Heino, M., Desmet, M. \& Di Giovanni, C., 2014. Tracking Holocene glacial and high-altitude alpine environments 
fluctuations from minerogenic and organic markers in proglacial lake sediments (Lake Blanc Huez, Western French Alps). Quaternary Science Reviews 89, 27-43.

Skilbeck, C.G., Rolph, T.C., Hill, N., Woods, J. \& Wilkens, R.H., 2005. Holocene millennial/centennial-scale multiproxy cyclicity in temperate eastern Australian estuary sediments. Journal of Quaternary Science 20, 327-347.

Sohar, K. \& Kalm, V., 2008. A 12.8-ka-long palaeoenvironmental record revealed by subfossil ostracod data from lacustrine freshwater tufa in Lake Sinijärv, northern Estonia. Journal of Paleolimnology 40, 809-821.

Stuiver, M. \& Braziunas, T.F., 1989. Atmospheric ${ }^{14} \mathrm{C}$ and century-scale solar oscillation. Nature 338, 405-408.

Tarand, A., Jaagus, J. \& Kallis, A., 2013. Eesti kliima minevikus ja tänapäeval [Estonian climate: Past and Present]. Tartu Ülikooli kirjastus, Tartu, 631 pp. [in Estonian with English summary].

Tarand, A. \& Nordli, P.Ø., 2001. The Tallinn temperature series reconstructed back half a millennium by use of proxy data. Climatic Change 48, 189-199.

Vaasma, T., 2008. Grain-size analysis of lacustrine sediments: a comparison of pre-treatment methods. Estonian Journal of Ecology 57, 231-243.

Veski, S., Seppä, H. \& Ojala, A.E.K., 2004. Cold event at $8200 \mathrm{yr}$ B.P. recorded in annually laminated lake sediments in eastern Europe. Geology 32, 8, 681-684.

Veski, S., Seppä, H., Stančikaitè, M., Zernitskaya, V., Reitalu, T., Gryguc, G., Heinsalu, A., Stivrins, N., Amon, L., Vassiljev, J. \& Heiri, O., 2014. Quantitative summer and winter temperature reconstructions from pollen and chironomid data between 15-8 ka BP in the Baltic-Belarus area. Quaternary International. (http://dx. doi.org/10.1016/j.quaint.2014.10.059).

Väli, V., Poska, A., Kihno, K., Alliksaar, T., Saarse, L., Tomson, P \& Vassiljev, J., 2014. Reconstructing past vegetation changes in Karula heights, South-Estonia over the last millennia. [In:] $9^{\text {th }}$ European Palaeobotany-Palynology Conference. Padova, Italy, p. 289.

Väliranta, M., Blundell, A., Charman, D.J., Karofeld, E., Korhola, A., Sillasoo, Ü. \& Tuittila, E.-S., 2012. Reconstructing peatland water tables using transfer functions for plant macrofossils and testate amoebae: A methodological comparison. Quaternary International 268, 34-43.

Väliranta, M., Korhola, A., Seppä, H., Tuittila, E.-S., Sarmaja-Korjonen, K., Laine, J. \& Alm, J., 2007. High-resolution reconstruction of wetness dynamics in a southern boreal raised bog, Finland, during the late Holocene: a quantitative approach. The Holocene 17, 1093-1107.

Walker, M.J..C., Berkelhammer, M, Björck, S., Cwynar, L.C., Fisher, D.A., Long, A.J., Lowe, J.J., Newnham, R.M., Rasmussen, S. \& Weiss, H., 2012. Formal subdivision of the Holocene Series/Epoch: a Discussion Paper by a Working Group of INTIMATE (Integration of ice-core, marine and terrestrial records) and the Subcommission on Quaternary Stratigraphy (International Commission on Stratigraphy). Journal of Quaternary Science 27, 649-659.

Wanner, H., Beer, J., Bütikofer, J., Crowley, T.J., Cubasch, U., Flückiger, J., Goosse, H., Grosjean, M., Joos, F., Kaplan, J.O., Küttel, M., Müller, S.A., Prentice, I.C., Solomina, O., Stocker, T.F., Tarasov, P., Wagner, M. \& Widmann, M., 2008. Mid- to Late Holocene climate change: an overview. Quaternary Science Reviews 27, 1791-1828.

Webb, R.S. \& Webb, III, T., 1988. Rates of sediment accumulation in pollen cores from small lakes and mires of eastern North America. Quaternary Research 30, 284-297.

Wu, J., Yu, Z., Zeng, H.A. \& Wang, N., 2009. Possible solar forcing of 400-year wet-dry climate cycles in northwestern China. Climate Change 96, 473-482.

Yu, Z. \& Ito, E., 1999. Possible solar forcing of century-scale drought frequency in the northern Great Plains. Geology 27, 263-266.

Yu, Z. \& Ito, E., 2003. The 400-year wet-dry climate cycle in interior North America and its solar connection. [In:] G.I. West \& N.L. Blomquist (Eds.): Proceedings of the $19^{\text {th }}$ Annual Pacific Climate Workshop. Sacramento, California, 159-163.

Manuscript submitted 3 October 2014 Revision accepted 19 January 2015 